\title{
GENETIC GAIN AND PROJECTED INCREASE IN STAND VOLUME FROM TWO CYCLES BREEDING PROGRAM OF Acacia mangium
}

\author{
Arif Nirsatmanto*, Teguh Setyaji, Sri Sunarti and Dwi Kartikaningtyas \\ Forest Biotechnology and Tree Improvement Research Center \\ Jl. Palagan Tentara Pelajar Km. 15, Purwobinangun, Yogyakarta, Indonesia
}

Received: 23 October 2013, Revised: 5 May 2015, Accepted: 11 May 2015

\begin{abstract}
GENETIC GAIN AND PROJECTED INCREASE IN STAND VOLUME FROM TWO CYCLES BREEDING PROGRAM OF Acacia mangium. Two cycles breeding program of Acacia mangium has been practiced by the Forest Biotechnology and Tree Improvement Research Center in Indonesia. Although improved seeds from the breeding program have been used in operational plantation, the real gains in productivity were not verified yet. This paper observes realized genetic gain and projected increase in stand volume from the two breeding cycles of $A$. mangium, and to discuss the implications on plantation productivity and sustainable forestry in Indonesia. Improved seeds from the first and second-generation seed orchards were tested together with an unimproved seed in genetic gain trial in West Java, with spacing of $3 \mathrm{x}$ $3 \mathrm{~m}$. Measurements were taken yearly until three years age for height, dbh, and stem volume. Realized genetic gain was calculated as the percentage increase of improved seed over the unimproved one. Results showed that the improved seeds performed better than the unimproved ones with realized gains of $5-24 \%$ (height), $3-44 \%$ (dbh) and 11-90\% (stem volume). Improved seeds from the second-generation outperformed the one from the first-generation, with an improvement of 6-16\% (height), 3-26\% (dbh) and 20-53\% (stem volume). Genetic gains increased with increasing ages for height, but it tended to decrease for dbh and stem volume. At a given site and silvicultural practices, projected increase in stand volume at 8 years rotation reached 290$325 \mathrm{~m}^{3} \mathrm{ha}^{-1}$, which is equal to $30-50 \%$ gain. The use of high genetically improved seeds, in combination with better silvicultural practices would provide significant impacts on plantation productivity and sustainable forestry in Indonesia.
\end{abstract}

Keywords: Acacia mangium, second-generation, stand volume, realized genetic gain, productivity

PERBAIKANGENETIKDANPROYEKSIPENINGKATANPRODUKTIVITAS VOLUME TEGAKAN DARI DUA GENERASI SIKLUS PEMULIAAN Acacia mangium. Dua generasi dalam siklus pemuliaan Acacia mangium telah dilakukan oleh Balai Besar Penelitian Bioteknologi dan Pemuliaan Tanaman Hutan. Tulisan ini mempelajari tingkat perbaikan genetik aktual dan proyeksi produktivitas volume tegakan sampai akbir daur, serta implikasinya pada produktivitas butan tanaman dan kelestarian butan di Indonesia. Benib unggul pemuliaan generasi pertama dan kedua diuji bersama dengan benih biasa (tidak dimuliakan) di dalam plot uji perbaikan genetik di Jawa Barat dengan jarak tanam operasional $3 \times 3 \mathrm{~m}$. Tinggi total, dbh dan volume batang diukur sampai tegakan umur 3 tahun. Perbaikan genetik aktual dibitung sebagai persentase peningkatan pertumbuhan tegakan dari benih unggul terbadap tegakan dari benih biasa. Secara umum, benih unggul menunjukean pertumbuhan tegakan yang lebih baik dibandingkan benih biasa, perbaikan genetik. berkisar 5-24\% (tinggi), 3-44\% (dbh) dan 11-90\% (volume batang). Benih unggul pemuliaan generasi ke-dua menunjukkan produktivitas yang lebih tinggi dibandingkan benib unggul pemuliaan generasi pertama, berkisar 6-16\% (tinggi), 3-26\% (dbb) dan 20-53\% (volume batang). Tingkat perbaikan genetik sifat tinggi meningkat dengan bertambahnya umur tanaman, tetapi cenderung menurun pada sifat dbh dan volume batang. Proyeksi produktivitas volume tegakan dari benih unggul (daur 8 tahun) mencapai 290-324 $\mathrm{m}^{3} /$ ha atau terjadi peningkatan sebesar 30-50\%. Penggunaan benih unggul dengan pola silvikulur yang baik akan mampu meningkatkan produktivitas hutan tanaman untuk. kelestarian butan di Indonesia.

Kata kunci: Acacia mangium, generasi ke-dua, volume tegakan, perbaikan genetik aktual, produktivitas

*Corresponding author: arif_nirz@yahoo.com 


\section{INTRODUCTION}

Acacia mangium is the most commonly planted species in Industrial Plantation Forest in Indonesia. This species shows high growth rates and produce high-quality wood for pulp and timber products in short rotation. Currently more than 1,000,000 hectares of $A$. mangium have been planted by several forest companies and has made a significant contribution to the Indonesian economy (Ministry of Forestry, 2010).

Indonesian government has targeted a total production of approximately 67 million $\mathrm{m}^{3}$ of wood per year for producing 16 million ton of pulp by 2020 (Manurung et al., 2007). The increased wood demand for pulp industries has stimulated a growing importance of expanding the large scale plantations of the high productive $A$. mangium. It is well known that tree improvement in combination with better silvicultural practices had proved to be one of the major contributors to the increase of the forest plantation productivity (Zobel \& Talbert, 1984).

Since 1993 the Center for Forest Biotechnology and Tree Improvement (CFBTI) has started a comprehensive tree improvement program for $A$. mangium. The program was implemented through establishing the firstgeneration seedling seed orchards, which was continued through the second-generation in 2000, in several regions such as Sumatra, Kalimantan and Java (Hashimoto, Kurinobu, \& Suhaendi, 1996; Kurinobu \& Rimbawanto, 2002). The two cycles of breeding programs had been completed and are now starting the third breeding cycle.

Realized gain from the first breeding cycle of A. mangium accounted around $13-30 \%$ for stand volume productivity which is equal to the production of around 250-290 $\mathrm{m}^{3} \mathrm{ha}^{-1}$ (Kurinobu, Arisman, Leksono, \& Hardiyanto, 2006). Based on the results of progeny trial, the second cycle breeding was estimated to produce approximately $5 \%$ more productivity than the first-cycle (Setyaji, 2011). Although improved seeds from the breeding program have been used in operational plantations, the total real amount of gains in terms of productivity from the two breeding cycles was not verified yet based on a common genetic gain trial. This paper observes the realized genetic gain and the projected increase in stand volume from the two breeding cycles of $A$. mangium, as well as its implications on plantation productivity and sustainable forestry in Indonesia.

\section{MATERIAL AND METHOD}

\section{A. Tested Materials}

Four improved stands of $A$. mangium were tested in this study which were derived from two seedling seed orchards originating from Papua New Guinea (PNG) provenances and two seedling seed orchards originating from Far North Queensland-Australia (FNQ) provenances. The two orchards in each provenance consisted of the first-generation and the second-generation orchards. Subline system was practiced in the seedling seed orchard establishment, and therefore the second-generation orchards were established using seeds from plus trees selected in the respective first-generation orchard and some additions from natural forest selections of the same provenances. As a comparison, unimproved stand was derived from local seed stand of Subanjeriji, which is genetically less productive than the improved stands, and was also used in this study. The seeds were collected from the respective seed sources, namely: four seedling seed orchards and one seed stand were then used for establishing the genetic gain trial.

\section{B. Genetic Gain Trial}

The genetic gain trial was established in 2009 in BKPH Jonggol, KPH Bogor, West Java (Figure 1), which is located at latitude of $6^{\circ} 28^{\prime} 3^{\prime \prime}$ South, longitude of $107^{\circ} 2^{\prime} 59^{\prime \prime}$ East, and altitude of $438 \mathrm{~m}$ above sea level. The climate type is A according to Schmidt and Ferguson's classification with an average temperature of $25^{\circ} \mathrm{C}$, and annual rainfall of $2,500 \mathrm{~mm}$. The predominant soil type is Grumusol and the topography is moderately sloping of around $5 \%$. 
The gain trial was arranged in randomized complete block design with four replications. In each replication, five set of bulk seeds collected from the five seed sources: two of the first-generation, two of the second-generation orchards, and one seed stand, were planted at spacing of $3 \times 3 \mathrm{~m}$. Within each plot, trees were planted in square grid pattern with a $10 \mathrm{x}$ 10 tree square.

The previous vegetation in the trial area was dominated by $A$. mangium stand. During site preparation, the area was cultivated manually through land clearing, followed by slashing and burning without plowing. The following years after planting, fertilizer was applied twice per year using 150 gram per tree of NPK (15:15:15) until 2 years of age. During the first year after planting weed control was carried out manually every four month in order to eliminate the competition of the weeds with the trees planted. The frequency of weeding was then reduced to two times per year for the second and third year due to canopy closure which inhibited the development of grassy weeds (Hardiyanto, 2004).

\section{Measurement and data analysis}

To get an accurate observation, only the inner 36 trees (6 66 trees) in each square plot were measured to simulate the competition that would occur between individual trees of the same seed source. During the first three years, trees planted in the trial were measured periodically once per year on two traits (height and diameter at breast height). Data on height and diameter were then used to calculate individual stem volume (v) using the volume equation (Inose, Saridi, \& Nakamura, 1992) :

$\nu=0.000058806 \times \mathrm{D}^{1.71772} \times \mathrm{H}^{1.0809}$

Realized genetic gain was calculated as the percentage increase of improved seed from the two breeding cycles over the unimproved one. In this purpose of study, single factor analysis of variance was then made to test the effects of each treatment separately: three generations, two populations and five seed sources.

Projected increase in stand volume at the rotation age ( 8 years age) were estimated from the three years height gains using the methods described by Kurinobu et al., (2006). Briefly, superiorities in height growth of improved stand over the unimproved stand were converted to the increase in site index (SI) with the equation as follows:

$\mathrm{H}_{\mathrm{T}}=h_{1}\left(t_{\mathrm{i}}\right)+\left[\mathrm{SI}-h_{1}(8)\right] \times h_{2}\left(t_{\mathrm{i}}\right) / h_{2}(8)$

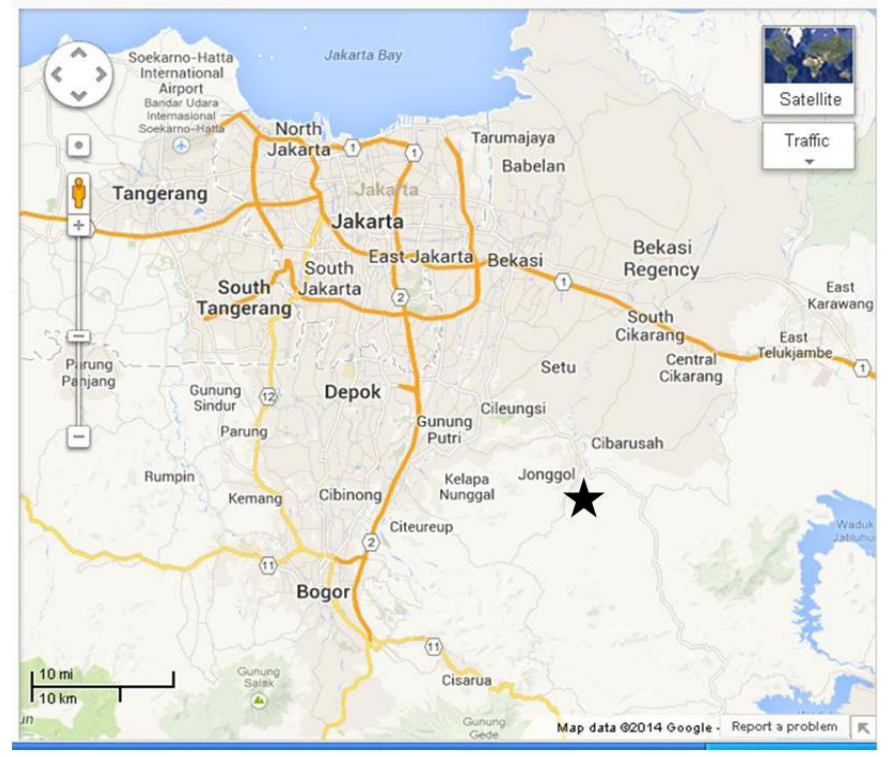

Figure 1. Site map of the location of Acacia mangium genetic gain trial in Jonggol, West Java Source : google map 
Where $h\left(t_{i}\right)$ and $h(8)$ were the height of the guide curve at age $t i$ and the height at the reference age ( $=8$ years) in this study.

The site index values were then used with the growth model described by Nirsatmanto, Kurinobu, and Hardiyanto (2003) to estimate the expected increase in stand volume at rotation age.

\section{RESULT AND DISCUSSION}

\subsection{Growth and Realized Genetic Gain}

In this study the growth of $A$. mangium planted in the trial established in West Java, above 9 meter for height and $12 \mathrm{~cm}$ for $\mathrm{dbh}$ at three years of age (Table 1), was generally comparable with the growth of the same species planted in one of the representative plantation areas of A. mangium in South Sumatera as reported by Hastanto (2009). The trial site was located in the concession area managed by Perhutani which has allocated it for $A$. mangium plantations. Thus, the site trial was suitable for the purpose of study.

Improved stand planted using seeds obtained from the two breeding cycles of $A$. mangium showed substantially better growth than the unimproved stand (Table 1). The growth rates of stand derived from the secondgeneration seedling seed orchards were higher than those derived from the first-generation. Over all, the realized genetic gain ranged from $5-24 \%$ for height, $3-44 \%$ for dbh and $11-90 \%$ for stem volume. The gain of the secondgeneration was substantially higher than that of the first-generation. By considering the fact that stem volume is the function of height and diameter, the stem volume has provided the highest genetic gain compared with the other two growth traits.

Improved stand derived from seedling seed orchard which has originated from PNG provenances tended to give a slightly slower growth than those originated from FNQ (Table 1). This result was not in agreement with previous reports of provenance trial (Harwood \& Williams, 1991; Kari, Otsamo, Kuusipalo,
Vuikko, \& Nikles, 1996) and genetic gain trial of first-generation improvement (Kurinobu et al., 2006), where PNG generally performed better in growth than the ones from FNQ. This is probably due to the damage by wind, broken tops that has occurred in some trees of PNG plot after two years which then affected the growth rates.

Regarding the progress from the two breeding cycles, the realized genetic gain of the second-generation over the first-generation ranged from 6 to $16 \%$ for height, 3 to $26 \%$ for dbh, and 20 to $53 \%$ for stem volume (Table 1). Stem volume provided the highest additional genetic gain compared to height and dbh. In general and despite the growth was slightly lower, the additional gain of the second generation over the first-generation was slightly higher for PNG than that for FNQ.

The significant difference level in the growth traits among the three generations breeding: unimproved, first-generation and secondgeneration, increased with increasing age (Table 2). All of the traits showed highly significant differences at three years of age. This indicated that the growth superiority resulted from the successive generation breeding was evident as the tree was getting older, with stem volume as the trait was substantially improved.

Among the two populations: unimproved and improved (first and second-generation seedling seed orchards) and among the five seed sources: seed stand (unimproved), two seedling seed orchards of PNG and two seedling seed orchards of FNQ, the significant difference level showed a similar trend among generations (Table 2). This indicated that gain from the two breeding cycles as described in preceding paragraphs was evident in the genetic gain trial. Therefore some improvement could be potentially obtained from utilizing the genetically improved seeds which were collected from the seed sources coming from the breeding program.

Basically, the realized gains achieved by the second-generation consisted of the accumulated total gains produced by the first-generation and 
Table 1. Mean and realized genetic gains (\%) of the first and the second-generation seedling seed orchards originating from Papua New Guinea (PNG) and Far North Queensland (FNQ) provenances

\begin{tabular}{|c|c|c|c|c|c|c|c|c|c|c|c|}
\hline \multirow{4}{*}{ Traits / year } & \multirow{4}{*}{$\begin{array}{c}\text { Unimproved } \\
\text { Mean } \\
\end{array}$} & \multicolumn{10}{|c|}{ Improved } \\
\hline & & \multicolumn{4}{|c|}{ First-generation } & \multicolumn{6}{|c|}{ Second-generation } \\
\hline & & \multicolumn{2}{|c|}{ PNG } & \multicolumn{2}{|c|}{ FNQ } & \multicolumn{3}{|c|}{ PNG } & \multicolumn{3}{|c|}{ FNQ } \\
\hline & & Mean & Gain $^{\mathrm{a}}$ & Mean & Gain $^{a}$ & Mean & Gain $^{\mathrm{a}}$ & Gain $^{\mathrm{b}}$ & Mean & Gain $^{a}$ & Gain $^{\text {b }}$ \\
\hline Height-1 (m) & 2.3 & 2.4 & 5.5 & 2.5 & 9.1 & 2.6 & 15.0 & 9.1 & 2.6 & 15.7 & 6.0 \\
\hline Height-2 (m) & 7.0 & 8.0 & 13.4 & 7.6 & 8.0 & 8.6 & 22.5 & 8.0 & 8.1 & 15.0 & 6.4 \\
\hline Height-3 (m) & 9.7 & 10.4 & 6.9 & 10.9 & 11.7 & 12.1 & 24.2 & 16.2 & 11.8 & 21.5 & 8.8 \\
\hline Dbh-1 (cm) & 1.9 & 1.9 & 3.6 & 2.2 & 17.3 & 2.5 & 31.2 & 26.7 & 2.7 & 44.2 & 23.0 \\
\hline Dbh-2 (cm) & 8.9 & 9.6 & 7.2 & 10.2 & 13.6 & 10.4 & 16.5 & 8.6 & 11.0 & 23.0 & 8.3 \\
\hline Dbh-3 $(\mathrm{cm})$ & 12.5 & 13.3 & 6.9 & 13.7 & 9.5 & 13.8 & 10.2 & 3.1 & 14.6 & 17.0 & 6.9 \\
\hline Volume-1 $\left(\mathrm{x} 10^{-3} \mathrm{~m}^{3}\right)$ & 0.6 & 0.7 & 11.3 & & 35.1 & 1.07 & 71.3 & 53.9 & 1.2 & 90.8 & 41.2 \\
\hline Volume-2 (x10-3 $\left.\mathrm{m}^{3}\right)$ & 19.6 & 25.6 & 30.4 & 25.3 & 28.7 & 32.3 & 64.5 & 26.2 & 30.6 & 55.5 & 20.8 \\
\hline Volume-3 $\left(\mathrm{x} 10^{-3} \mathrm{~m}^{3}\right)$ & 47.7 & 56.1 & 17.8 & 63.0 & 32.1 & 76.6 & 60.7 & 36.5 & 78.6 & 64.8 & 24.7 \\
\hline
\end{tabular}

Remarks : a gains (\%) over unimproved stand

b gains $(\%)$ over first-generation

Table 2. Observed significance associated with the analysis of variance for three years measurements of height, dbh and stem volume

\begin{tabular}{|c|c|c|c|c|c|c|c|c|c|c|}
\hline \multirow{3}{*}{$\begin{array}{l}\text { Source of } \\
\text { Variance }\end{array}$} & \multirow{3}{*}{ df } & \multicolumn{9}{|c|}{$\mathrm{p}$-value } \\
\hline & & \multicolumn{3}{|c|}{ height / year } & \multicolumn{3}{|c|}{$\mathrm{dbh} /$ year } & \multicolumn{3}{|c|}{ stem volume / year } \\
\hline & & 1 & 2 & 3 & 1 & 2 & 3 & 1 & 2 & 3 \\
\hline Generation & 2 & $0.336^{\text {ns }}$ & $0.068^{\mathrm{ns}}$ & $0.008^{* *}$ & $0.138^{\text {ns }}$ & $0.022^{*}$ & $0.008^{* *}$ & $0.078^{\text {ns }}$ & $0.037^{*}$ & $0.002^{* *}$ \\
\hline Population & 1 & $0.226^{\mathrm{ns}}$ & $0.066^{\mathrm{ns}}$ & $0.034 *$ & $0.212^{\mathrm{ns}}$ & $0.022^{*}$ & $0.007^{* *}$ & $0.147^{\mathrm{ns}}$ & $0.052^{\mathrm{ns}}$ & $0.020 *$ \\
\hline Seed Source & 4 & $0.711^{\mathrm{ns}}$ & $0.195^{\text {ns }}$ & $0.047 *$ & $0.375^{\text {ns }}$ & $0.074^{\mathrm{ns}}$ & $0.017 *$ & $0.271^{\mathrm{ns}}$ & $0.178^{\text {ns }}$ & $0.022 *$ \\
\hline
\end{tabular}

Remarks: ${ }^{* *}$ significant at the level 1\%, * significant at the level 5\%, ns : not significant

the additional gain from the second-generation. The accumulative gains from the two successive generations of breeding cycles could be clearly observed in this study as presented in Figure 2. The amount of total gains produced by the second-generation, which was calculated directly from the percentage superiority of the second-generation over the unimproved stand, were similar to the sum of the total gains from the first-generation and the additional gains of the second-generation over the first-generation, except for stem volume which was slightly higher. Thus it confirmed that by subtracting the total gain of the first-generation seedling seed orchards, the second-generation seedling seed orchards produced additional gain ranging from 6 to $17 \%$ for height, 3 to $27 \%$ for dbh, and 26 to $60 \%$ for stem volume. These gains were similar to the gains calculated directly as the percentage superiority of the secondgeneration over the first-generation (Table 1). The accumulated gains from the secondgeneration seedling seed orchards as observed in this study indicated that the improvement work through the two breeding cycles had been done properly and their impacts on the stand productivity were verified well in the genetic gain trial.

Genetic gain slightly increased with increased age for height, but it tended to 
decrease for dbh and stem volume (Figure $3)$, despite the trend of significant difference level between populations: improved and unimproved, increased with age (Table 2). The decrease in gains were probably due to the effect of increasing inter-tree competition from more rapid stand development, either due to improved stand or productive site quality, which then tended to reduce the amount of genetic gain. Eldridge (1982) has reported a small genetic gain in productive site indicating decreasing genetic gains with increasing stand development and competition. In addition, diameter and stem volume are the traits which are sensitive to inter-tree competition (Clutter, Fortson, Pienaar, Britster, \& Bailey, 1983).

\subsection{Projected increase in stand volume}

The projected increase in stand volume at the rotation age (8 years) was estimated from the three-year's age of height gains. The results of the average stand volume projection of stand derived from the two breeding cycles are presented in Figure 4. At given site and silvicultural practice, volume of unimproved stand derived from seed stand as a control was estimated at approximately $217 \mathrm{~m}^{3} \mathrm{ha}^{-1}$ at eight years of age, and it was similar to the volume of the same genetic resource reported previously in other gain trial in South Kalimantan (Kurinobu et al., 2006). Whereas the stand volume of improved stand derived from the two breeding cycles reached $290-325 \mathrm{~m}^{3} \mathrm{ha}^{-1}$, with the average of each generation was around $278 \mathrm{~m}^{3} \mathrm{ha}^{-1}$ for the first-generation seedling seed orchard and $314 \mathrm{~m}^{3} \mathrm{ha}^{-1}$ for the second-generation.

Superiority of improved stand over the unimproved one resulted in genetic gains for stand volume at 8 years rotation age ranging from 27 to $44 \%$ (Figure 4). Subsequently, the second-generation seedling seed orchards produced additional 13\% stand volume gain over the first-generation seedling seed orchard. By assuming the current national plantation productivity baseline of around $200 \mathrm{~m}^{3} \mathrm{ha}^{-1}$ (Manurung et al., 2007), utilizing the genetically improved seeds, which are collected from the seed sources resulting from the two breeding cycles program, one could be expecting to increase the productivity in stand volume by 30 to $50 \%$.

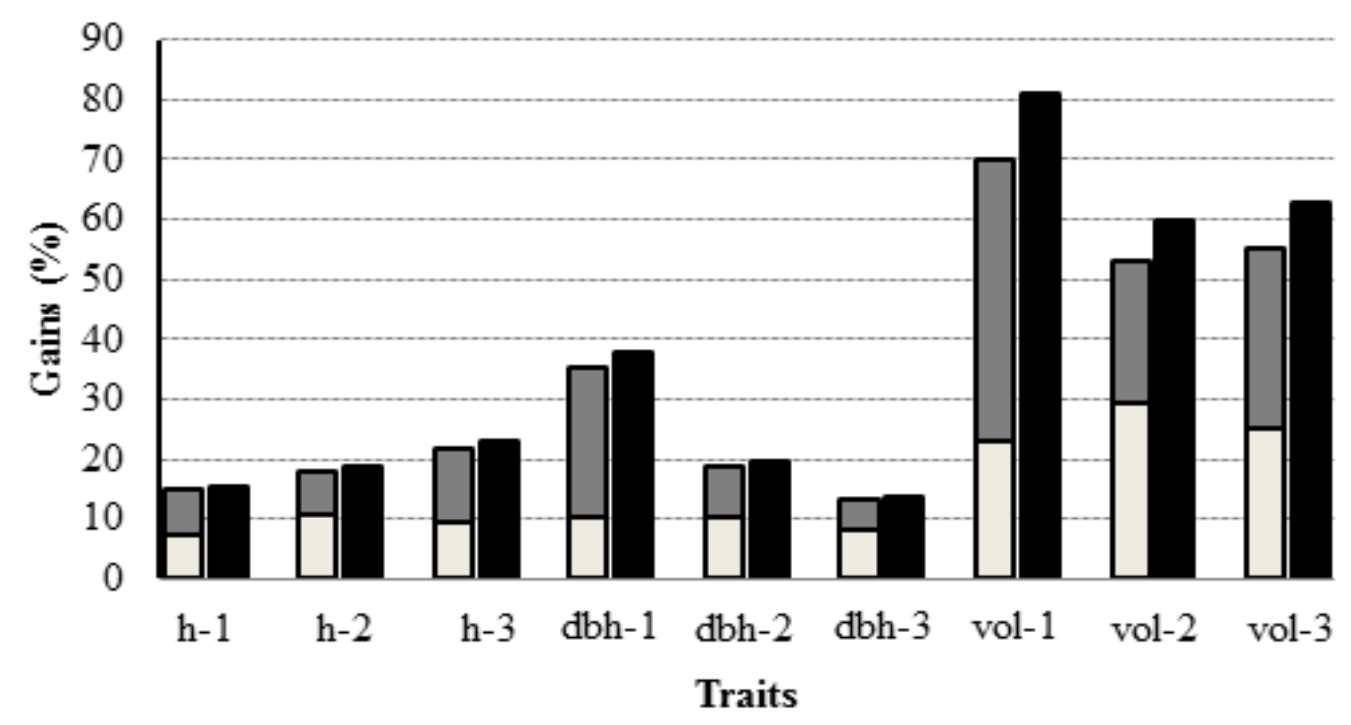

Figure 2. Average realized gains (\%) of PNG and FNQ in the first-generation (white) and the second-generation seedling seed orchards (black) over unimproved stand, and gains of the second-generation over the first-generation (grey) for three year's measurements of height (h-1, h-2, h-3), dbh (dbh-1, dbh-2, dbh-3) and stem volume (vol-1, vol-2, vol-3) 


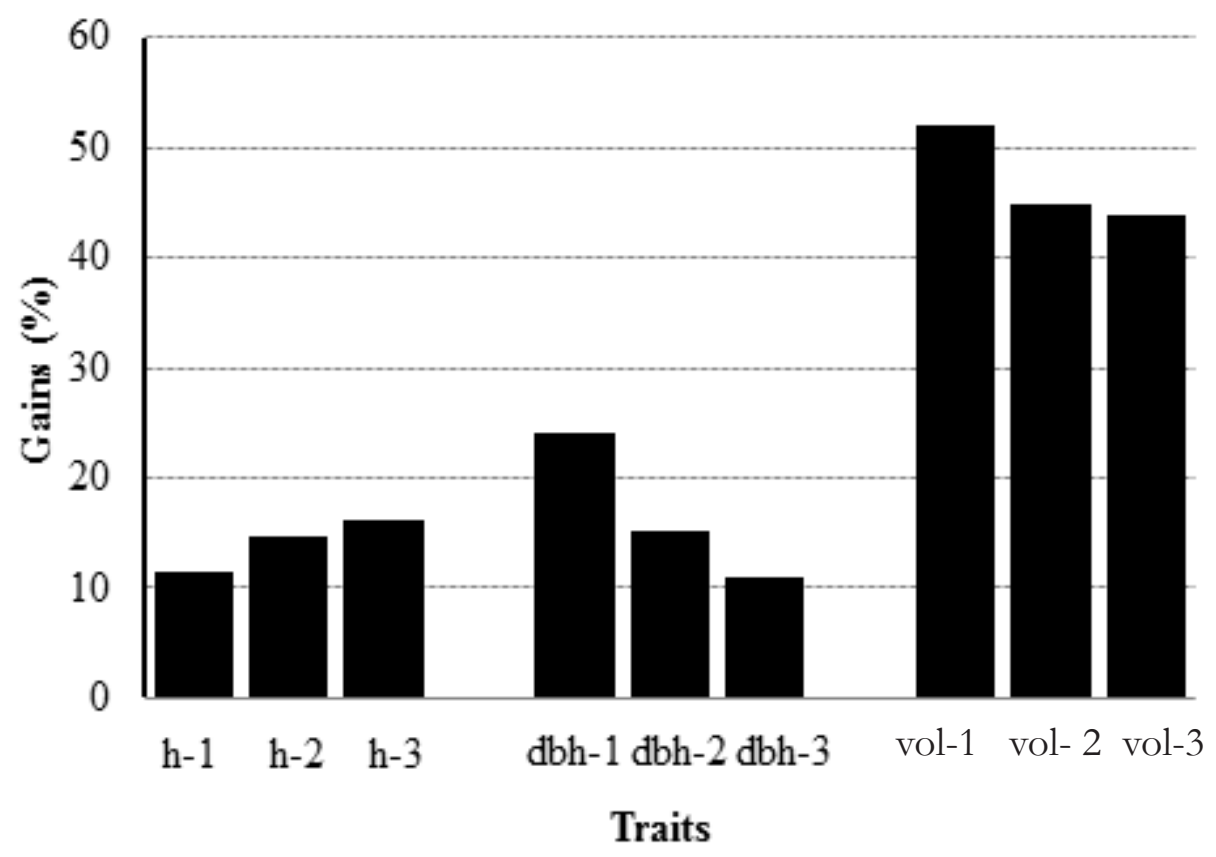

Figure 3. The average gains (\%) across the two breeding cycles (the first and the second-generation seedling seed orchards) over unimproved stand for three year's measurements of height (h-1, h-2, h-3), dbh (dbh-1, dbh-2, dbh-3) and stem volume (vol-1, vol-2, vol-3)

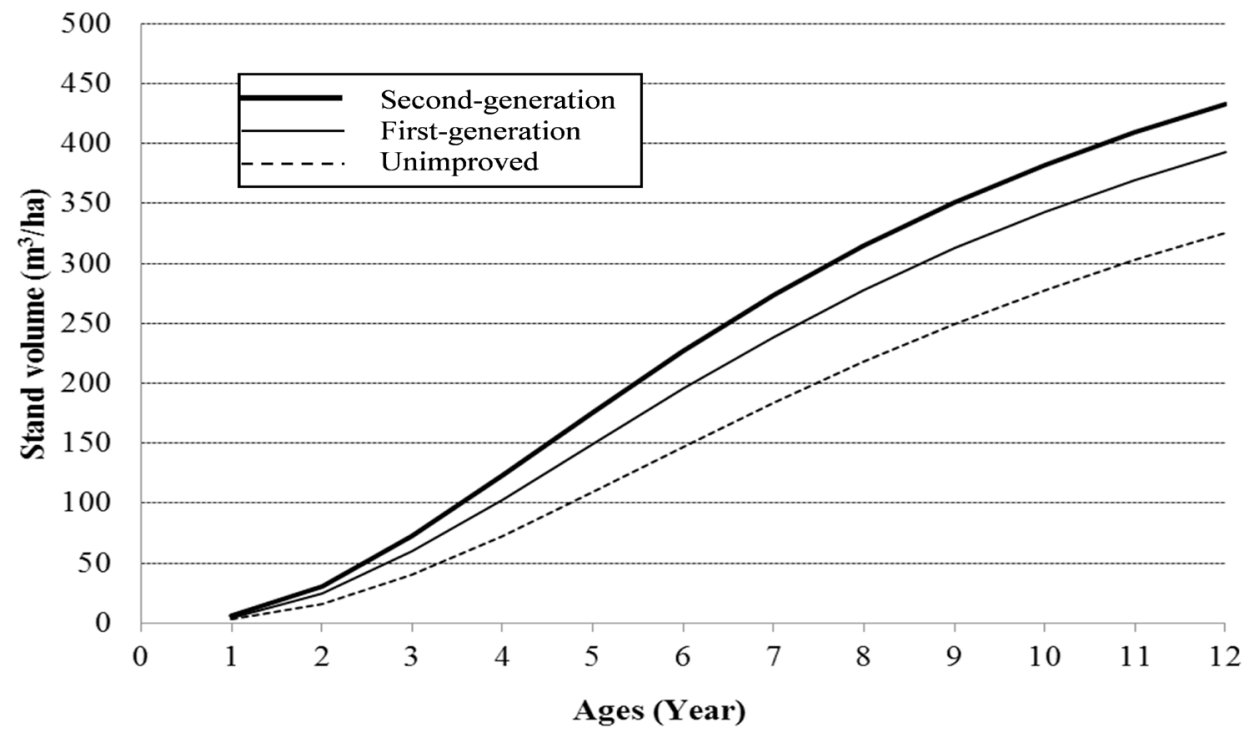

Figure 4. A projected increase in the average stand volume $\left(\mathrm{m}^{3} / \mathrm{ha}\right)$ for the improved stand derived from two cycles breeding compared to unimproved stand

\subsection{Implications on plantation productivity and sustainable forestry}

The increased target for pulpwood production of up to 67 million $\mathrm{m}^{3}$ per year will result a deficiency in supply of pulpwood of around $50 \%$ with current plantation productivity baseline $\left(200 \mathrm{~m}^{3} \mathrm{ha}^{-1}\right)$. However, according to the high gains resulted in this study, which is around $30-50 \%$ more stand volume at the harvesting age over the baseline, it suggests that 
the impacts of tree improvement on plantation forest productivity would be substantial from the two cycles breeding of $A$. mangium. Using the genetically improved seeds from the breeding program it could be possible to increase the plantation productivity ranging from 278$314 \mathrm{~m}^{3} \mathrm{ha}^{-1}$. Furthermore, by considering the annual plantation capacity of around 200,000 hectares as mentioned in preceding paragraph, it is estimated that a total of 55- 63 million $\mathrm{m}^{3}$ of pulpwood would be produced from these improved $A$. mangium. Although the estimated wood production would be slightly less than the targeted production $\left(67\right.$ million $\left.\mathrm{m}^{3}\right)$, additional improvement from wood quality traits could be expected to be other source to increase pulp yield production through reducing wood consumption per ton pulp.

Considering the continued high target of pulp industries with the probable limitation of availability of productive commercial land, and the anticipation of probable impacts of climate change, stand volume productivity must be increased simultaneously. According to the results of this study, tree improvement program combined with best silvicultural practices had proved to be one of the most effective way to meet the future increased demand of high stand productivity. The impact of using wood from high productive plantation of $A$. mangium will significantly reduce the logging pressure on natural forests. This is because the wood demand for the industries could be fully supplied by wood harvested from improved plantations. Regarding these facts, it was revealed that the available genetically improved seed of $A$. mangium from the two cycles breeding could be the potential to provide a significant contribution for increasing plantation productivity and sustainable forestry in Indonesia. However, to achieve the target quantity of improved seeds, further multiplying of the seedling seed orchards from these two breeding cycles in mass scale (up to 100 hectares) should be undertaken to meet the demand for the targeted plantation establishment. In addition, the improvement of wood properties should also be included in the next breeding program to complete the improvement of growth traits. In the future, to increase the utility of the improved seed for another locally end product of $A$. mangium such as solid wood, it is necessary also to examine the productivity of the improved seed over the available local stand volume tables.

\section{CONCLUSION}

The substantial realized genetic gain from the two breeding cycles of $A$. mangium was verified in genetic gain trial, with approximately $30-50 \%$ more production in stand volume $\left(\mathrm{m}^{3} / \mathrm{ha}\right)$ over the current national plantation productivity baseline. This result indicated that the tree improvement work for $A$. mangium had been done properly and their impact on stand productivity was evident. By utilizing the highly productive genetically improved seeds for plantation forest establishment, that will provide a significant impact to reduce logging pressure on natural forest and to maintain the sustainability of forestry in Indonesia. Therefore, it is recommended to multiply the seedling seed orchards resulted from this two cycles breeding in mass scale to meet the demand of genetically improved seeds for the targeted plantations.

\section{ACKNOWLEDGEMENT}

We would like to express our sincere gratitude to PERUM PERHUTANI, on whose land the trial was established, for establishing and maintaining the trials. Without this support the study would not have been possible. We thank Mr. Surip and Mr. Sumaryana for all the fieldwork and data collection.

\section{REFERENCES}

Clutter, J. L., Fortson, J. C., Pienaar, L. V., Britste, G. H., \& Bailey, R. L. (1983). Timber management: quantitative approach. New York, USA: John Willey \& Sons.

Eldridge, K. G. (1982). Genetic improvements from a radiate pine seed orchard. New Zealand Journal of Forest Science, 12, 404-411.

Hardiyanto, E. B. (2004). Acacia mangium - Silviculture and Breeding (in Bahasa Indonesia). In E. B. Hardiyanto \& H. Arisman (Eds.), Industrial 
Plantation Forest Development: Experiences in PT . Musi Hutan Persada, South Sumatra . (pp. 207-268). Yogyakarta: Polydor.

Harwood, C. E., \& Williams, E. R. (1991). A review of provenance variation in growth of Acacia mangium. In L. T. Carron \& K. M. Aken (Eds.), Breeding Technologies for Tropical Acacias. Proceeding of a Workshop held in Tawau, Sabab, Malaysia, 14 July 1991. ACLAR Proceeding 37 (pp. 22-30).

Hashimoto, K., Kurinobu, S., \& Suhaendi, H. (1996). Establishment of seed sources of tropical tree species in Indonesia. In Tree improvement for sustainable tropical forestry. Proceeding of the QFRI-IUFRO Conference, Caloundra, Australia. 27 October - 1 November 1996 (pp. 370-371).

Hastanto, H. (2009). The Role of yielding seeds to increase the productivity of Acacia mangium plantations in PT . Musi Hutan Persada (in Bahasa Indonesia). In B. Leksono, A. AYPBC Widyatmoko, \& A. Nirsatmanto (Eds.), Prosiding Ekspose Hasil-Hasil Penelitian: Status Terkini Penelitian Pemuliaan Tanaman Hutan, Yogyakarta, 1 Oktober 2009 (pp. 136-146).

Inose, M., Sarid, Z., \& Nakamura, T. (1992). Growth analysis of Acacia mangium. Hoppo Ringyo, 2, 17-19.

Kari, T., Otsamo, A., Kuusipalo, J., Vuokko, R., \& Nikles, G. (1996). Effect of provenance variation and singling and pruning on early growth of Acacia mangium Willd. Plantation on Imperata cylindrica (L.) Beauv., dominated grassland. Forest Ecology Management, 84, 241 249.

Kurinobu, S., Arisman, H., Leksono, B., \& Hardiyanto, E. B. (2006). An impact of genetic improvement on the plantation management of Acacia mangium assessed by a growth model with size-density relationship. In Proceeding of international seminar on plantation forest research and development, 21-23 November 2005, Yogyakarta, Indonesia (pp. 120-124). Yogyakarta: Centre for
Plantation Forest Research and Development. Kurinobu, S., \& Rimbawanto, A. (2002). Genetic improvement of plantation species in Indonesia-Summary of Project Achievement (JICA Forest Tree Improvement Phase II). In A. Rimbawanto \& M. Susanto (Eds.), Proceedings of international conference on advances in genetic improvement of tropical tree species, 1-3 October 2002, Yogyakarta, Indonesia. Yogyakarta: Centre for Forest Biotechnology and Tree Improvement.

Manurung, E. G. T., Simangunsong, B. C., Sukadri, D. S., Widyantoro, B., Justianto, A., Ramadhan, S., Supriyanto, B. (2007). The revitalization of Indonesia's forestry industry (in Bahasa Indonesia) (p. 60). Jakarta: In-House Experts Working Group Revitalisasi Industri Kehutanan Departemen Kehutanan.

Ministry of Forestry. (2010). Opening address by The Minister of Forestry on International Seminar Research on Plantation Forest: Challenges and Opportunities. In Proceeding International Seminar on Plantation Forest Management: Challenges and Opportunities, 5-6 November 2009, Bogor, Indonesia. Bogor: Center for Plantation Forest Research and Development.

Nirsatmanto, A., Kurinobu, S., \& Hardiyanto, E. B. (2003). A projected increase in stand volume of introduced provenances of Acacia mangium in seedling seed orchards in South Sumatra, Indonesia. Journal of Forest Research, 8, 127-131.

Setyaji, T. (2011). Genetic x Environment interaction on the second-generation (F-2) of Acacia mangium Willd., breeding seedling orchard in four locations in Sumatera and Kalimantan (Thesis, in Bahasa Indonesia) (p.50). Graduate School of Gadjah Mada University, Yogyakarta

Zobel, B.J. and J. Talbert. 1984. Applied forest tree improvement. John Wiley \& Sons. New York. $505 p$. 